\title{
Upaya Meningkatkan Kompetensi Peserta Didik dalam Menulis Pantun Melalui Model Pembelajaran Kooperatif-Keliling Kelompok
}

\section{Efforts Improving Competence of Students in Writing Poem Through Cooperative Learning Model-Roving Group}

\author{
Rini Sofiah Rohatini* \\ SMP Negeri 2 Ciparay, Kabupaten Bandung, Jawa Barat, Indonesia \\ rdrinisofiah@gmail.com*
}

Naskah diterima tanggal 26/04/2021, direvisi akhir tanggal 27/04/2021, disetujui tanggal 29/04/2021

\begin{abstract}
Abstrak
Penelitian tindakan kelas ini dilaksanakan di SMPN 2 Ciparay Kabupaten Bandung. Subyek penelitian ini adalah siswa kelas VII C SMP Negeri 2 Ciparay Kabupaten Bandung berjumlah 28 orang dan dilaksanakan dari Bulan januari sampai Pebruari 2018. Saat penelitian dilaksanakan, data diperoleh melalui hasil nilai yang mengukur kompetensi siswa, angket, jurnal harian dan observasi. Instrumen utama dalam penelitian ini adalah peneliti sendiri yang dilengkapi dengan instrumen lain berupa lembar observasi. Berdasarkan daya serap rata-rata, tiap siklus mengalami peningkatan yaitu pada siklus I daya serap rata-rata sebagian besar (67.67), terjadi kenaikan pada siklus II sebagian besar (74.28) dan siklus 3 pada umumnya (82.32). Demikian juga dengan daya serap klasikal mengalami peningkatan, pada tindakan 1/siklus 1 sebagian kecil (25\%) pada siklus 2 sebagian besar (42.85\%) dan pada siklus 3 pada umumnya (75\%). Data di atas didukung oleh sikap positif peserta didik terhadap pembelajaran Bahasa Indonesia dengan menggunakan Model Pembelajaran Kooperatif-Keliling Kelompok (melalui angket dan jurnal harian peserta didik. Selain itu, ada perubahan prilaku peserta didik dan guru ke arah positif yaitu: peserta didik terlihat memiliki motivasi belajar; guru memberikan penjelasan mengenai urutan cara kerja yang dicantumkan dalam latihan; peserta didik dimotivasi untuk lebih aktif dan mandiri; guru telah memberikan teguran sehingga masih ada peserta didik yang melakukan kegiatan di luar petunjuk serta membimbing peserta didik mencari contoh penerapan di kehidupan sehari-hari. Penelitian ini menghasilkan perubahan motivasi dan prestasi peserta didik karena di atas $65 \%$ peserta didik memiliki motivasi yang sangat tinggi. Dengan demikian penggunaan Model Pembelajaran Kooperatif-Keliling Kelompok secara empiris dapat meningkatkan kompetensi peserta didik dalam pembelajaran Bahasa Indonesia di kelas VII C SMP Negeri 2 Ciparay Kabupaten Bandung Tahun Pelajaran 2017/2018.
\end{abstract}

Kata kunci: Kompetensi Peserta Didik; Kooperatif-Keliling Kelompok; Model Pembelajaran, Penelitian Tindakan Kelas.

\begin{abstract}
This classroom action research was conducted at SMPN 2 Ciparay, Bandung Regency. The subjects of this study were 28 class VII C students of SMP Negeri 2 Ciparay, Bandung Regency, and carried out from January to February 2018. When the research was carried out, data was obtained through values that measure student competence, questionnaires, daily journals, and observations. The main instrument in this research is the researcher himself, who is equipped with another instrument in an observation sheet. Based on the average absorption capacity, each cycle experienced an increase; namely, in-process $I$, the average absorption capacity
\end{abstract}


mainly was (67.67), there was an increase in cycle II mostly (74.28) and cycle 3 in general (82.32). Likewise, classical absorption has increased, in action 1 / cycle one a small part (25\%) in cycle two mostly (42.85\%) and in cycle 3 in general (75\%). The data above is supported by the positive attitudes of students towards Indonesian language learning using the Cooperative Learning Model - Around Groups (through questionnaires and students' daily journals. In addition, there are changes in the behavior of students and teachers in a positive direction. Namely, students appear to have motivation. Learning; the teacher explains the order of work included in the exercise; students are motivated to be more active and independent; the teacher has given a warning so that there are still students who carry out activities outside the instructions and guide students to find examples of application in everyday life This study resulted in changes in the motivation and achievement of students because more than $65 \%$ of students had very high motivation. Thus, the Cooperative-Group Tour Model's use empirically could improve students' competence in learning Indonesian in class VII CS. MP Negeri 2 Ciparay, Bandung Regency, Academic Year 2017/2018.

Keywords: Student Competencies; Cooperative-Group Tour; Learning Model, Classroom Action Research 


\section{PENDAHULUAN}

Dalam rangka era informasi global dewasa ini, semakin terasa perlunya mengkomunikasikan gagasan secara tertulis, tidak terkecuali di kalangan SMP. Pada dasarnya semua peserta didik mempunyai banyak pengalaman yang dapat dijadikan titik acuan untuk menulis, misalnya pengalaman yang berkenaan dengan harapan, kekhawatiran, keinginan, ambisi, peristiwa masa lalu dan sebagainya.

Menurut beberapa informasi dan pengamatan, ternyata kegiatan Menulis Pantun bagi peserta didik SMP, masih rendah dibandingkan dengan kegitan berbahasa lainnya (Indrayeni et al., 2019).

Dalam kaitannya dengan pengajaran bahasa dan sastra Indonesia di SMP, Menulis Pantun merupakan salah satu bahan pembelajaran apresiasi sastra (kesusastraan) yang tersirat dalam komponen pemahaman dan penggunaan (Sulkifli \& Marwati, 2016).

Ketika pelaksanaanya, ada tiga komponen pengajaran bahasa yaitu kebahasaan, pemahaman, dan penggunaan hendaknya disajikan secara terpadu (integratif) dengan demikian, bahan pengajaran pantun, hendaknya terkait pula dengan komponen pengajaran dan unsur kebahasaan.

Tujuan pembelajaran sastra di SMPN 2 Ciparay belum tercapai secara optimal sebagai guru pengajar bahasa dan sastra Indonesia yaitu sebagian peserta didik menikmati pengajaran sastra (pantun) hanya merupakan suatu yang indah untuk dibaca dan didengarkan, tanpa dipahami dan dihayati secara lebih mendalam pesan yang disampaikan dalam pantun tersebut.

Ketidakberhasilan pengajaran apresiasi pantun di kalangan peserta didik SMPN 2 Ciparay ini disebabkan berbagai faktor diantaranya: peserta didik sulit menangkap serta memahami isi atau sesuatu yang tersirat dalam pantun mempunyai sifat, struktur dan bentuk sendiri; dan ketidakberhasilan pengajaran sastra disebabkan guru keliru atau kurang tepat, penyajian bahan ajar pun kurang baik, berakibat pada proses belajar mengajar kurang berhasil.

Akibat penerapan model pengajar yang kurang tepat, penyajian bahan ajar yang kurang baik, berakibat proses belajar mengajar kurang berhasil. Berbagai model mengajar dan pendekatan dapat diterapkan untuk mengajarkan sesuatu materi pembelajaran.

Model pembelajaran memiliki sintaks (pola urutan tertentu) dari suatu model pembelajaran sebagai pola yang menggambarkan urutan alur tahap-tahap keseluruhan yang pada umumnya disertai dengan serangkaian kegiatan pembelajaran (Darmadi, 2017).

Model pembelajaran pada kurikulum 2013 memiliki kriteria sebagai berikut (Suhana, 2014):

a. Materi pembelajaran berbasis pada fakta atau fenomena yang dapat dijelaskan dengan logika atau penalaran tertentu, bukan sebatas kira-kira, khayalan, legenda, atau dongeng semata.

b. Penjelasan guru, respon siswa, dan interaksi edukatif guru-siswa terbebas dari prasangka yang serta-merta, pemikiran subjektif, atau penalaran yang menyimpang dari alur berpikir logis.

c. Mendorong dan menginspirasi siswa berpikir secara kritis, analitis, dan tepat dalam mengidentifikasi, memahami, memecahkan masalah, dan mengaplikasikan materi pembelajaran.

d. Mendorong dan menginspirasi siswa mampu berpikir hipotetis dalam melihat perbedaan, kesamaan, dan tautan satu sama lain dari materi pembelajaran. Mendorong dan menginspirasi siswa mampu memahami, menerapkan, dan mengembangkan pola berpikir yang rasional dan objektif dalam merespon materi pembelajaran.

e. Berbasis pada konsep, teori, dan fakta empiris yang dapat dipertanggungjawabkan.

f. Tujuan pembelajaran dirumuskan secara sederhana dan jelas, namun menarik sistem penyajiannya.

g. Proses pembelajaran dalam kurikulum 2013 menyentuh tiga ranah, yaitu sikap, pengetahuan, dan keterampilan. Sehingga menghasilkan peserta didik yang produktif, kreatif, inovatif, dan afektif melalui penguatan sikap, keterampilan, dan pengetahuan yang 
terintegrasi.

Salah satu contoh model pembelajaran adalah sistem pengajaran yang memberi kesempatan kepada anak didik untuk bekerja sama dengan sesama siswa dalam tugas-tugas yang terstruktur. Pembelajaran kooperatif dikenal dengan pembelajaran secara berkelompok (Taniredja, 2013).

Pembelajaran kooperatif tipe keliling kelompok (Round Club) yaitu masing-masing anggota kelompok mendapatkan kesempatan untuk memberikan kontribusi mereka dan mendengarkan pandangan serta pemikiran anggota lain (Lie, 2010). Hal ini harus didukung dengan kompetensi yang mempuni.

Menurut Musfah (2011) kompetensi merupakan kemampuan individu yang mencakup pengetahuan, keterampilan, dan sikap yang diwujudkan dalam hasil kerja nyata yang membawa manfaat bagi dirinya serta lingkungan di sekitarnya. Oleh karena itu kompetensi selain mencakup pengetahuan, sikap, dan keterampilan, tetapi tujuannya juga harus disesuaikan dengan kebutuhan dan lingkungan sekitar.

Mata pelajaran sebagai sumber dari konten untuk menguasai kompetensi bersifat terbuka dan tidak selalu diorganisasikan berdasarkan disiplin ilmu yang sangat berorientasi. Majid (2014) berpendapat bahwa kompetensi dasar berisi konten atau kompetensi yang terdiri atas sikap, pengetahuan, dan keterampilan yang bersumber pada kompetensi inti yang harus dikuasai peserta didik.

Adapun pengukuran kompetensi itu sendiri menurut Dimyati dan Mudjiono (2009) menyebutkan enam jenis perilaku ranah kognitif yaitu (1) Pengetahuan, mencapai kemampuan ingatan tentang hal yang telah dipelajari dan tersimpan dalam ingatan, pengetahuan yang berkenaan dengan fakta, peristiwa, pengertian, kaidah, teori, prinsip; (2) Pemahaman, mencakup kemampuan menangkap arti dan makna tentang hal yang dipelajari.; (3) Penerapan, mencakup kemampuan menerapkan metode, dan kaidah untuk menghadapi masalah yang nyata dan baru, misalnya menggunakan prinsi; (4) Analisis, mencakup kemampuan merinci suatu kesatuan ke dalam bagian-bagian sehingga struktur keseluruhan dapat Bahasa Indonesia dengan baik, misalnya mengurangi masalah menjadi bagian yang lebih kecil; (5) Sintesis, mencakup kemampuan membentuk suatu pola baru, misalnya kemampuan menyusun suatu program; dan (6) Evaluasi, mencakup kemampuan membentuk pendapat tentang beberapa hal berdasarkan kriteria tertentu, misalnya, kemampuan menilai hasil belajar.

Menurut Abidin (2012) menyebutkan bahwa Bahasa Indonesia merupakan alat untuk berkomunikasi secara lisan dan tulis. Berkomunikasi adalah memahami dan mengungkapkan informasi, pikiran, perasaan, dan mengembangkan ilmu pengetahuan, teknologi, dan budaya. Oleh karena itu, mata pelajaran bahasa Indonesia diarahkan untuk mengembangkan keterampilan-keterampilan agar lulusan mampu berkomunikasi dan berwacana dalam bahasa Indonesia pada tingkat literasi tertentu.

Menurut Sukarto (2010) pembelajaran menulis memiliki empat tujuan yaitu menginformasikan segala sesuatu, membujuk, mendidik, dan menghibur. Begitu juga dalam menulis sebuah puisi rakyat.

Puisi rakyat adalah karya sastra berupa puisi, syair, pantun, dan gurindam yang memiliki nilai-nilai yang ingin diwariskan para leluhur (Harsiati, 2016). Salah satu dari karya sastra yakni pantun. Pangesti (2014) menyebutkan bahwa pantun termasuk ke dalam jenis puisi lama yang berasal dari bahasa Melayu yang dipopulerkan di Indonesia. Terdiri atas empat larik (baris), larik pertama dan kedua sebagai sampiran, larik ketiga dan keempat sebagai isi, bersajak $a-b-a-b$.

\section{METODE PENELITIAN}

Metodologi Penelitian Tindakan Kelas ini memaparkan tentang langkah-langkah penelitian kelas yang akan disampaikan, sehingga tujuan penelitian ini dapat dicapai sesuai dengan rancangan yang telah dirumuskan. Hasil akhir yang ingin dicapai dalam penelitian ini adalah meningkatnya kompetensi peserta didik dalam pelajaran Bahasa Indonesia di kelas VII C SMP Negeri 
2 Ciparay Kabupaten Bandung tahun pelajaran 2017/2018. Untuk mencapai tujuan tersebut, maka penelitian yang digunakan adalah Penelitian Tindakan Kelas (Classroom Action Research).

Dalam upaya memecahkan permasalahan dengan melakukan tindakan dalam proses pembelajaran diperlukan data-data yang dapat dipercaya. Karena itu dalam upaya pengumpulan data dan mengolahnya diperlukan kerjasama dengan pihak lainnya sebagai partner kerja dalam upaya memecahkan permasalahan yang lain. Oleh karena itu, bentuk penelitian yang digunakan adalah bentuk kolaboratif dengan guru bidang studi yang bersangkutan. Langkah-langkah bentuk penelitian tindakan kelas yang peneliti lakukan sistem spiral refleksi model Kemmis dan MC Taggart (Sukidin et al., 2008).

Subjek penelitian dalam Penelitian Tindakan Kelas ini adalah peserta didik kelas VII.C SMP Negeri 2 Ciparay Kabupaten Bandung Tahun Pelajaran 2017/2018, jumlah peserta didik kelas tersebut adalah 28 orang. Penelitian ini dilaksanakan dari Bulan Februari sampai Maret 2018 dengan pelaksanaan siklus 1 hari Kamis tanggal 8 Februari 2018, pelaksanaan siklus 2 hari Kamis tanggal 15 Pebruari 2018, dan pelaksanaan siklus 3 hari Kamis tanggal 22 Pebruari 2018.

Agar tujuan penelitian ini tercapai dan untuk memperoleh data yang konkret, maka dalam penelitian ini digunakan instrumen adalah catatan Lapangan, butir soal; angket; jurnal harian, dan photo.

Data yang telah diperoleh pada setiap tahapan tindakan penelitian dianalisis sebagai berikut.

\subsection{Kategorisasi Data}

Data yang dianalisis sebelumnya terlebih dahulu dikategorikan berdasarkan fokus penelitian. Data dalam penelitian ini adalah tingkat penguasaan peserta didik dan daya serap kelas setelah mengikuti pembelajaran Bahasa Indonesia dengan menggunakan Model Pembelajaran Kooperatif-Keliling Kelompok.

2.2. Interpretasi Data

a. Menganalisis Data Tes Hasil Belajar Menganalisis data berupa tes hasil belajar peserta didik untuk mengetahui keberhasilan yang telah dilakukan. Indikator keberhasilan penelitian tindakan ini adalah ketuntasan belajar dan daya serap klasikal (DSK). Suatu kelas disebut telah tuntas belajarnya bila kelas tersebut telah mencapai $85 \%$ peserta didik mencapai daya serap $>65 \%$ (Depdikbud No. 4 Tahun 2018). Untuk menghitung persentase di atas dapat menggunakan rumus sebagai

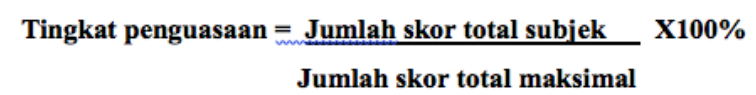

DSK $=\left(\sum\right.$ peserta didik yang memperoleh tingkat penguasaan $\left.>65 \%\right) \times 100 \%$ Jumlah peserta didik

berikut.

b. Menganalisis Angket Peserta Didik

Angket peserta didik dihitung dengan menggunakan rumus:

Presentase alternatif jawaban $=$ Alternatif jawaban $X 100 \%$ Jumlah sampel

Data angket yang telah terkumpul, dihitung dan ditabulasikan serta dipresentasikan seluruh jawaban peserta didik yang memilih setiap indikator. Setelah dipresentasikan kemudian ditafsirkan ke dalam kalimat yang bersifat kualitatif. Klasifikasi interpretasi perhitungan persentase tiap kategori menurut Suherman (2003) pada tabel 1:

Tabel 1. Persentase Tiap Kategori

\begin{tabular}{|c|c|}
\hline Besar Persentase & Interpretasi \\
\hline $0 \%$ & Tidak ada \\
\hline $1 \%-25 \%$ & Sebagian kecil \\
\hline $26 \%-49 \%$ & Hampir setengahnya \\
\hline $50 \%$ & Setengahnya \\
\hline $51 \%-75 \%$ & Sebagian besar \\
\hline $76 \%-99 \%$ & Pada umumnya \\
\hline $100 \%$ & Seluruhnya \\
\hline
\end{tabular}

c. Menganalisis Jurnal Peserta Didik Menganalisis jurnal peserta didik dengan mengelompokkan pendapat peserta didik ke dalam kelompok pendapat atau komentar positif, negatif, biasa berkomentar, kemudian 
dihitung persentasenya.

\subsection{Validasi Data}

Agar data yang diperoleh sahih dan andal, maka dilakukan teknik triangulasi, yaitu dengan melakukan beberapa tindakan yaitu antara lain: melakukan pengecekan ulang dari data yang telah terkumpul untuk kelengkapannya; melakukan pengolahan data dan analisis ulang dari data yang terkumpul; membuat perangkat tes; dan pembuatan lembar observasi untuk penulis/guru dan peserta didik pedoman cara dan angket serta instrumen lainnya.

\subsection{Pelaksanaan Tindakan}

Penggunaan Model Pembelajaran Kooperatif-Keliling Kelompok yang memiliki tahapan yaitu guru menyampaikan materi yang akan disajikan, dan KD yang ingin dicapai; mengobservasi aktivitas peserta didik dan guru/peneliti selama berlangsungnya proses pembelajaran, melakukan tes setelah pembelajaran setiap kali pertemuan; menyebarkan angket kepada peserta didik; menyebarkan jurnal harian kepada peserta didik.

\subsection{Evaluasi}

Pelaksanaan tes kelompok; Pelaksanaan tes akhir; observasi guru/peneliti dan peserta didik (lampiran); diskusi balikan antara observer dan guru (lampiran); angket untuk peserta didik (lampiran); jurnal Harian (lampiran).

\subsection{Analisis dan Refleksi}

Refleksi merupakan proses berfikir untuk melihat kembali tindakan yang telah dilakukan serta menentukan solusinya berdasarkan hasil observasi dari temuan di kelas pada saat pembelajaran berlangsung. Berdasarkan kajian itu disusun rancangan baru untuk diterapkan pada proses pembelajaran berikutnya di kelas dan oleh penulis yang sama.

\section{HASIL DAN PEMBAHASAN}

\subsection{Hasil}

Sebelum pelaksanaan tindakan pembelajaran, peneliti terlebih dahulu mengadakan observasi lapangan yang bertujuan untuk menemukan permasalahan yang berhubungan dengan proses pembelajaran Bahasa Indonesia.

1. Deskripsi Hasil Observasi Kegiatan Pembelajaran Pra-Tindakan (Pra-Siklus)

Observasi kegiatan pembelajaran pratindakan bertujuan untuk melihat bagaimana proses pembelajaran yang biasa diikuti oleh peserta didik di kelas. Sehingga peneliti dapat membuat rencana perbaikan yang akan dilakukan.

Berdasarkan hasil observasi pra tindakan, terlihat bahwa dalam proses pembelajaran, guru cenderung menggunakan metode ceramah dengan tanya jawab yang menoton dan tidak menggunakan pendekatan dan model pembelajaran yang relevan dengan materi pelajaran. Guru hanya terpaku pada buku paket, guru menjelaskan materi yang dipelajari, memberikan contoh kemudian meminta peserta didik untuk mengerjakan beberapa soal latihan. Peserta didik hanya mencatat sesekali menjawab (secara bersamaan) pertanyaan yang diberikan oleh guru dan mengerjakan tugas individu yang diberikan oleh guru.

Kegiatan pembelajaran cenderung kaku dan kurang kondusif. Frekuensi peserta didik yang bertanya tentang hal-hal yang berhubungan dengan materi yang dipelajari sangat kecil bahkan sama sekali tidak ada peserta didik yang bertanya. Dalam proses pembelajaran belum terlihat guru memberikan perhatian khusus kepada setiap peserta didik. Guru masih memperlakukan peserta didik secara menyeluruh sehingga tidak diketahui apa yang menjadi masalah atau hambatan belajar masing-masing individu.

Walaupun suasana relatif sepi, namun bukan berarti peserta didik mengikuti proses pembelajaran dengan baik. Ada peserta didik yang berbisik dengan peserta didik lainnya, ada peserta didik yang bersikap malas, dan ada juga peserta didik yang asyik dengan kesibukannya di luar konteks pembelajaran, terlihat suasana kelas sangat tidak kondusif dan melelahkan.

2. Refleksi terhadap Hasil Kegiatan Pra Tindakan

Berdasarkan orientasi pada kegiatan pra tindakan, melalui observasi awal yang telah 
dilakukan oleh peneliti, diperoleh refleksi sebagai berikut tabel 2

Tabel 2. Refleksi Kegiatan Pra Tindakan

\begin{tabular}{|c|c|}
\hline Masalah & Saran-Saran Perbaikan \\
\hline $\begin{array}{l}\text { Peserta didik belum } \\
\text { terlibat dalam } \\
\text { pembelajaran yang } \\
\text { aktif, kreatif, inovatif } \\
\text { dan menyenangkan. } \\
\text { Peserta didik } \\
\text { cenderung pasip dalam } \\
\text { belajar. } \\
\text { - Peserta didik terbiasa } \\
\text { dengan pembelajaran } \\
\text { yang berpusat pada } \\
\text { guru. } \\
\text { Peserta didik kurang } \\
\text { termotivasi untuk } \\
\text { belajar Bahasa } \\
\text { Indonesia. } \\
\text { Peserta didik merasa } \\
\text { belajar Bahasa } \\
\text { Indonesia kurang } \\
\text { menarik. } \\
\text { Hasil belajar Bahasa } \\
\text { Indonesia peserta didik } \\
\text { masih rendah hal } \\
\text { tersebut membuktikan } \\
\text { bahwa kompetensi } \\
\text { pengetahuannya masih } \\
\text { rendah. }\end{array}$ & 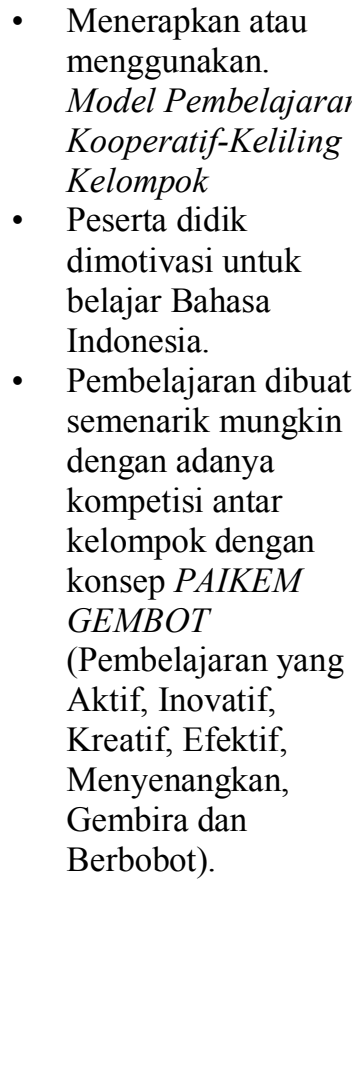 \\
\hline
\end{tabular}

\subsection{Pembahasan}

\subsubsection{Hasil Temuan Tindakan Pembelajaran Tindakan I / Siklus I}

A. Deskripsi Persiapan Tindakan I/Siklus I

Penelitian Tindakan Kelas ini, dilakukan pada hari Kamis, tanggal 8 Februari 2018, dengan persiapan-persiapan yang sesuai dengan tahap-tahap penelitian. Persiapan yang dilakukan untuk melaksanakan tindakan I/siklus 1 adalah penyusunan Rencana Pembelajaran Tindakan I/Siklus I, lembar tugas peserta didik hasil pengamatan motivasi peserta didik tindakan I/Siklus I, tes dalam bentuk soal uraian, pedoman observasi untuk mencatat proses pembelajaran yang dilakukan oleh peneliti / guru dan peserta didik dan jurnal harian untuk memperoleh gambaran tanggapan peserta didik terhadap hasil pembelajaran dengan menggunakan Model Pembelajaran Kooperatif-Keliling Kelompok dan daftar kehadiran peserta didik pada tindakan I/Siklus I.
Proses pembelajaran pada tindakan I/Siklus I diikuti oleh seluruh peserta didik kelas VII.C SMP Negeri 2 Ciparay Kabupaten Bandung yang berjumlah 28 orang, Kompetensi Dasar adalah 4.9 menyimpulkan isi puisi rakyat (pantun, syair, dan bentuk puisi rakyat setempat) yang disajikan dalam bentuk lisan dan tulisan. 4.10 Mengungkapkan gagasan, perasaan, pesan dalam bentuk puisi rakyat secara lisan dan tulis dengan memperhatikan struktur, rima, dan penggunaan bahasa.

B. Deskripsi Pelaksanaan Tindakan I/Siklus

Pada awal pembelajaran, peneliti/guru memberitahu bahwa materi yang akan diberikan adalah materi pokok menulis pantun. Kegiatan guru/peserta didik selama kegiatan pembelajaran lebih rinci dapat dilihat pada urutan di bawah ini.

1) Pendahuluan

Guru mengabsen peserta didik; guru melaksanakan apersepsi; dan guru mengkondisikan kelas.

2) Kegiatan inti

Guru membagi kelompok siswa menjadi kelompok kecil; guru memanggil ketua kelompok masing masing untuk diberikan pengarahan dan tugas kelompok; guru membagikan kertas kartoon untuk ditempel di dinding; guru memberikan permasalahan tentang "Pantun"untuk didiskusikan masingmasing kelompok; guru mengkondisikan siswa untuk menulis hasil temuannya di kertas karton lalu menempelnya di dinding; guru memberikan kesempatan kepada kelompokkelompok kecil saling berkunjung ke kelompok lain untuk melihat pekerjaan kelompok yang lain; dan masing-masing anggota kelompok mendapatkan kesempatan untuk memberikan kontribusi dan mendengarkan pengalaman anggota lain.

3) Kegiatan penutup

Guru dan peserta didik membuat kesimpulan bersama; guru mengkondisikan siswa untuk melaksanakan tes akhir; dan penutup, guru dan siswa berdoa bersama.

C. Deskripsi Nilai Tes Kompetensi Peserta didik, Aktivitas Peserta Didik dan Guru pada Tindakan I/Siklus I

Hasil nilai rata-rata harian tertinggi 
adalah 90 , terendah 45 dan rata-ratanya adalah 67.67, jumlah peserta didik yang mengalami ketuntasan belajar sebanyak 7 orang $(25 \%)$. Dengan demikian hasil belajar peserta didik pada tindakan I/Siklus 1 perlu ditingkatkan pada tindakan selanjutnya (tindakan 2 / siklus 2).

Berdasarkan hasil pengamatan, pada tindakan I Siklus1 ini yaitu guru menyampaikan materi yang akan disajikan, dan KD yang ingin dicapai namun guru/peneliti tidak mengecek pengetahuan awal peserta didik melalui apersepsi. Kemudian guru membentuk peserta didik berkelompok, lalu memanggil masing-masing ketua kelompok untuk memberikan penjelasan tentang materi namun terlihat peserta didik terlihat kurang motivasi belajar.

Masing-masing ketua kelompok kembali ke kelompoknya masing-masing, kemudian menjelaskan materi yang disampaikan oleh guru kepada temannya. Guru membagikan contoh teks pantun berbahasa Indonesia. Peserta didik kurang termotivasi untuk lebih aktif dan mandiri. Kemudian setelah masingmasing peserta didik diberikan satu lembar kertas kerja, untuk menuliskan satu pertanyaan apa saja yang menyangkut materi yang sudah dijelaskan oleh ketua kelompok. Kelompok menuliskan hasil temuan tentang pantun di kertas karton lalu menempelnya di dinding.

Kelompok saling mengunjungi kelompok lain kemudian membaca hasil kelompok lain dan memberi komentar. Saat kelompok siswa berkeliling melihat kelompok lainnya maka diberikan kesempatan kepada peserta didik untuk bertanya atau menjawab pertanyaan. Guru tidak membimbing peserta didik mencari contoh-contoh penerapan konsep dalam kehidupan sehari-hari.

Saat kegiatan penutup, guru dan peserta didik membuat kesimpulan namun tidak bersama-sama, kemudian peserta didik melaksanakan tes akhir berupa tes untuk mengukur kompetensi peserta didik dalam Menulis Pantun. Terakhir guru menutup pelajaran dengan berdoa.

\footnotetext{
D. Refleksi dan Revisi Tindakan I/Siklus I Menurut data observasi lapangan dan
}

hasil evaluasi tes I secara umum, maka peneliti/guru dan observer mengidentifikasi masalah untuk memperbaiki tindakan pembelajaran yaitu berdasarkan hasil tes I, pada umumnya nilai peserta didik kurang memuaskan dan masih banyak yang di bawah KKM, oleh karena itu perlu upaya perbaikan dan peningkatan hasil belajar peserta didik pada tindakan 2/siklus 2; peserta didik terlihat kurang motivasi belajar; guru/peneliti tidak mengecek pengetahuan awal peserta didik melalui apersepsi; peserta didik kurang termotivasi untuk lebih aktif dan mandiri; guru/peneliti kurang memberikan teguran sehingga masih ada peserta didik yang melakukan kegiatan di luar petunjuk; guru tidak membimbing peserta didik mencari contoh-contoh penerapan konsep dalam kehidupan sehari-hari; guru /peneliti tidak sempat membimbing peserta didik dalam membuat kesimpulan secara bersama.

Berdasarkan kekurangan yang ada pada pelaksanaan tindakan I/ siklus 1, maka pada pelaksanaan pembelajaran berikutnya (tindakan 2/ siklus 2) perlu memperhatikan perbaikan-perbaikan yaitu peneliti diharapkan memotivasi peserta didik dengan bahwa pembelajaran bahasa Indonesia sangat penting bagi mereka; guru/peneliti membuka pelajaran dengan melakukan tanya jawab atau apersepsi mengenai materi pelajaran sebelumnya; peneliti/guru mengarahkan peserta didik untuk berada dalam kelompoknya masing-masing untuk berdiskusi secara aktif; guru/peneliti langsung membimbing peserta didik dalam melakukan pengamatan dari satu kelompok ke kelompok lainnya; peserta didik harus dimotivasi untuk lebih aktif dan mandiri; peneliti/guru memberikan teguran kepada peserta didik yang melakukan kegiatan di luar pembelajaran; guru diharapkan membimbing peserta didik mencari contoh-contoh penerapan konsep dalam kehidupan seharihari; dan guru /peneliti diharapkan membimbing peserta didik dalam membuat kesimpulan secara bersama-sama.

\subsubsection{Hasil Temuan Tindakan Pembelajaran Tindakan II / Siklus II} A. Deskripsi Persiapan Tindakan II/Siklus II 
Penelitian Tindakan Kelas pada siklus 2 ini dilaksanakan pada hari Kamis tanggal 15 Pebruari 2018, dilakukan dengan persiapanpersiapan yang sesuai dengan tahap-tahap penelitian. Persiapan yang dilakukan untuk melaksanakan tindakan 2/siklus 2 sama dengan persiapan pada tindakan I/ siklus 1, hanya pada tindakan 2 siklus 2 merupakan hasil perbaikan dan diskusi balikan dari tindakan I. Adapun persiapan tindakan 2 /siklus 2 adalah penyusunan Rencana Pembelajaran Tindakan 2/siklus 2, lembar tugas peserta didik Tindakan 2/siklus 2, hasil pengamatan motivasi peserta didik pada tindakan Tindakan 2/siklus 2 tes dalam uraian Tindakan 2/siklus 2 pedoman observasi untuk mencatat proses pembelajaran yang dilakukan oleh peneliti /guru dan peserta didik pada Tindakan 2/siklus 2), dan jurnal harian untuk memperoleh gambaran tanggapan peserta didik terhadap hasil pembelajaran Tindakan 2/siklus 2, daftar hadir peserta didik selama Tindakan 2/siklus 2 berlangsung.

B. Deskripsi Pelaksanaan Tindakan
II/Siklus II
Pada awal pembelajaran, peneliti/guru memberitahu bahwa materi yang akan diberikan adalah materi pokok Menulis Pantun. Kegiatan guru/peserta didik selama kegiatan pembelajaran lebih rinci dapat dilihat seperti rencana Pelaksanaan Pembelajaran siklus 1.

C. Deskripsi Nilai Tes Kompetensi Peserta

Didik, Aktivitas Peserta Didik dan Guru pada Tindakan II/Siklus II

Hasil nilai rata-rata harian tertinggi adalah 100 terendah 60, dan rata-ratanya adalah 74.28, jumlah peserta didik yang mengalami ketuntasan belajar sebanyak 12 orang $(42.85 \%)$. Dengan demikian hasil belajar peserta didik pada Tindakan 2/siklus 2 perlu ditingkatkan pada tindakan selanjutnya (tindakan 3).

Berdasarkan hasil pengamatan, pada Tindakan 2/siklus 2 ini yaitu guru menyampaikan materi yang akan disajikan, dan KD yang ingin dicapai namun guru/peneliti telah mengecek pengetahuan awal peserta didik melalui apersepsi. Kemudian guru membentuk peserta didik berkelompok kecil, lalu memanggil masing- masing ketua kelompok untuk memberikan penjelasan tentang materi namun terlihat peserta didik masih terlihat kurang motivasi belajar. Masing-masing ketua kelompok kembali ke kelompoknya masing-masing, kemudian menjelaskan materi yang disampaikan oleh guru kepada temannya. Guru membagikan teks pantun.

Peserta didik telah dimotivasi untuk lebih aktif dan mandiri. Kemudian setelah masingmasing peserta didik diberikan satu lembar kertas kerja untuk berargumen tentang "Pantun dalam kelompok kecilnya, guru telah membimbing peserta didik mencari contohcontoh penerapan konsep dalam kehidupan sehari-hari. Saat kegiatan penutup, guru dan peserta didik membuat kesimpulan bersamasama, kemudian peserta didik melaksanakan tes akhir berupa Menulis Pantun. Terakhir guru menutup pelajaran dengan berdoa.

D. Refleksi dan Revisi Tindakan II/Siklus II Menurut data observasi lapangan dan hasil evaluasi tes 2 secara umum, maka peneliti/guru dan observer mengidentifikasi masalah untuk memperbaiki tindakan pembelajaran di antaranya sebagai berikut (1) Para peserta didik sudah mulai termotivasi dan terlihat antusias saat kelompok berdiskusi; (2) Nilai tes peserta didik sudah menunjukkan adanya peningkatan; Guru/peneliti telah mengecek pengetahuan awal peserta didik melalui apersepsi secra tepat. (4) Seluruh peserta didik telah dimotivasi untuk lebih aktif dan mandiri; (5) Guru telah membimbing peserta didik mencari contoh-contoh penerapan konsep dalam kehidupan sehari-hari

Namun meskipun demikian, tindakan 2 masih memperlihatkan adanya kekurangan, diantaranya (1) Guru/peneliti masih kurang memberikan teguran sehingga masih ada peserta didik yang melakukan kegiatan lainnya; (2) Peneliti/guru belum memberikan pujian bagi peserta didik yang memiliki motivasi yang tinggi.

Berdasarkan kekurangan yang ada pada tindakan 2, maka perlu diadakan perbaikanperbaikan yaitu sebagai berikut (1) Mempertahankan kelebihan yang telah didapat pada siklus 2; (2) Peneliti harus memberikan teguaran dan peringatan kepada 
peserta didik yang melakukan kegiatan di luar petunjuk namun tetap tanpa menyakiti perasaan mereka; dan (3) peneliti/guru tidak memberikan pujian bagi peserta didik yang memiliki motivasi yang tinggi.

\subsubsection{Hasil Temuan Tindakan Pembelajaran Tindakan III / Siklus III}

A. Deskripsi Persiapan Tindakan III/Siklus III

Siklus 3 ini dilaksanakan pada hari Kamis, tanggal 22 Pebruari 2019. Persiapan yang dilakukan untuk melaksanakan tindakan 3/siklus 3 ini sama dengan persiapan tindakan II, hanya pada tindakan 3/siklus 3 merupakan hasil perbaikan dan diskusi balikan dari tindakan 2.

B. Deskripsi Pelaksanaan Tindakan III/Siklus III

Pada awal pembelajaran, peneliti/guru mengulas sedikit materi pelajaran yang kurang dipahami sebelumnya (tindakan 2) serta hasil tes 2, lalu membagikan hasil tes 2 untuk memotivasi peserta didik supaya nilai tes berikutnya bisa lebih baik memberitahu bahwa materi yang akan diberikan adalah materi pokok Menulis Pantun. Kegiatan guru/peserta didik selama kegiatan pembelajaran seperti pelaksanaan pembelajaran siklus 1 dan siklus 2 .

C. Deskripsi Nilai Tes Kompetensi Peserta

Didik, Aktivitas Peserta Didik dan Guru pada Tindakan III/Siklus III

Hasil nilai rata-rata harian tertinggi adalah 100 terendah 70, dan rata-ratanya 82.32, jumlah peserta didik yang mengalami ketuntasan belajar sebanyak 21 orang $(75 \%)$. Dengan demikian 3/siklus 3 ini mengakhiri pembelajaran yang menggunakan Model Pembelajaran Kooperatif-Keliling Kelompok, karena nilai rata-rata tes dan daya serap klasikal nilai peserta didik di atas 65 sudah berada di atas $85 \%$.

Hasil observasi mengenai aktivitas peserta didik menunjukkan bahwa peserta didik telah melaksanakan tahapan Model Pembelajaran Kooperatif-Keliling Kelompok yaitu meliputi tahap : guru menyampaikan materi yang akan disajikan, dan KD yang ingin dicapai; guru membentuk peserta didik dalam kelompok kecil, lalu memanggil masing-masing ketua kelompok untuk memberikan penjelasan tentang materi; guru membagikan teks Menulis Pantun; masingmasing ketua kelompok kembali ke kelompoknya masing-masing, Guru memberikan permasalahan tentang "Pantun" untuk didiskusikan masing-masing kelompok. Guru memberikan kesempatan kepada kelompok-kelompok kecil saling berkunjung ke kelompok lain untuk melihat pekerjaan kelompok yang lain. Masing-masing anggota kelompok mendapatkan kesempatan untuk memberikan kontribusi dan mendengarkan pengalaman anggota lain.

Guru sudah mulai memberikan motivasi secara intensif kepada para peserta didiknya dan peserta didik bersama guru telah bersamasama membuat kesimpulan dengan baik dan tepat.

Pada akhir tindakan pembelajaran, peneliti mengadakan tes $3 /$ siklus 3 dalam bentuk soal uraian.

D. Refleksi dan Revisi Tindakan III/Siklus III

Menurut data observasi lapangan dan hasil evaluasi tes 3 secara umum, menunjukkan bahwa aktivitas peserta didik telah melaksanakan berbagai tahapan dengan baik meliputi: guru menyampaikan materi yang akan disajikan, dan KD yang ingin dicapai; guru membentuk peserta didik berkelompok, lalu memanggil masing-masing ketua kelompok untuk memberikan penjelasan tentang materi; guru membagikan teks pantun; masing-masing ketua kelompok kembali ke kelompoknya masing-masing, kemudian menjelaskan materi yang disampaikan oleh guru kepada temannya.

Guru memberikan permasalahan tentang "Pantun" untuk didiskusikan masing-masing kelompok. Guru memberikan kesempatan kepada kelompok-kelompok kecil saling berkunjung ke kelompok lain untuk melihat pekerjaan kelompok yang lain. Masingmasing anggota kelompok mendapatkan kesempatan untuk memberikan kontribusi dan mendengarkan pengalaman anggota lain. Guru sudah mulai memberikan motivasi secara intensif kepada para peserta didiknya dan peserta didik bersama guru telah bersama- 
sama membuat kesimpulan dengan baik dan tepat.

Pada akhir tindakan pembelajaran, peneliti mengadakan tes 3/siklus 3 dalam bentuk soal uraian dan Menulis Pantun.

\subsubsection{Analisis Nilai Tes}

Pengukuran keberhasilan pembelajaran dengan menggunakan Model Pembelajaran Kooperatif-Keliling Kelompok, dilakukan analisis daya serap peserta didik kelas VII C SMP Negeri 2 Ciparay Kabupaten Bandung Tahun Pelajaran 2017/2018 terhadap konsep ketuntasan hasil belajar (daya serap klasikal) untuk setiap tindakan. Data hasil tes dari bentuk soal uraian berikut di bawah ini.

a) Hasil Siklus I, nilai rata-rata harian tertinggi adalah 90, terendah 45 dan rata-ratanya adalah 67.67, jumlah peserta didik yang mengalami ketuntasan belajar sebanyak 7 orang (25\%). Dengan demikian hasil belajar peserta didik pada tindakan I/Siklus 1 perlu ditingkatkan pada tindakan selanjutnya (tindakan II/ siklus 2).

b) Hasil Siklus 2, nilai rata-rata harian tertinggi adalah 100 terendah 60, dan rata-ratanya adalah 74.28 , jumlah peserta didik yang mengalami ketuntasan belajar sebanyak 12 orang (42.85\%). Dengan demikian hasil belajar peserta didik pada Tindakan 2/siklus 2 perlu ditingkatkan pada tindakan selanjutnya (tindakan 3 ).

c) Hasil Siklus 3, nilai rata-rata harian tertinggi adalah 100 terendah 70, dan rata-ratanya 82.32 , jumlah peserta didik yang mengalami ketuntasan belajar sebanyak 21 orang (75\%). Dengan demikian 3/siklus 3 ini mengakhiri pembelajaran yang menggunakan Model Pembelajaran KooperatifKeliling Kelompok, karena nilai ratarata tes dan daya serap klasikal nilai peserta didik di atas 65 sudah berada di atas $85 \%$.

Tabel 3. Persentase Daya Serap dan Daya Serap Klasikal untuk setiap Siklus

\begin{tabular}{|c|c|c|c|}
\hline Tingkat Penguasan & $\begin{array}{c}\text { Persentase } \\
\text { Tindakan } \\
\text { Siklus }\end{array}$ & & \\
\hline & I & II & III \\
\hline Daya Serap Tertinggi & 90 & 100 & 100 \\
\hline Daya Serap Terendah & 45 & 60 & 70 \\
\hline Daya Serap Rata-rata & 67.67 & 74.28 & 82.32 \\
\hline Daya Serap Klasikal & $25 \%$ & $\begin{array}{c}42.85 \\
\%\end{array}$ & $75 \%$ \\
\hline
\end{tabular}

Berdasarkan pada tabel 3 daya serap rata-rata, maka pada siklus I daya serap ratarata sebagian besar (67.67), terjadi kenaikan pada siklus II sebagian besar (74.28) dan siklus 3 pada umumnya (82.32). Demikian juga dengan daya serap klasikal mengalami peningkatan, pada tindakan I sebagian kecil (25\%) pada siklus 2 sebagian besar $(42.85 \%)$ dan pada siklus III pada umumnya (75\%). Data di atas didukung oleh sikap positif peserta didik terhadap pembelajaran Bahasa Indonesia dengan menggunakan Model Pembelajaran Kooperatif-Keliling Kelompok (melalui angket dan jurnal harian peserta didik).

\subsubsection{Angket Sikap Peserta Didik}

Angket ini digunakan untuk mengetahui sikap peserta didik terhadap pembelajaran Bahasa Indonesia dengan menggunakan Model Pembelajaran Kooperatif-Keliling Kelompok. Angket diedarkan pada peserta didik setelah selesai seluruh pelaksanaan pembelajaran tindakan. Lembar angket berisi 10 pernyataan. Para peserta didik yang belajar dengan menggunakan Model Pembelajaran Kooperatif-Keliling Kelompok diminta pendapatnya mengenai penggunaan Model Pembelajaran Kooperatif-Keliling Kelompok dalam pembelajaran Bahasa Indonesia tersebut dengan menentukan salah satu pilihan ya atau tidak yang sesuai dengan sikapnya untuk pernyataan-pernyataan yang diajukan. Hasil angket peserta didik dianalisis dengan menghitung banyaknya jenis sikap untuk setiap pernyataan.

\subsubsection{Hasil Jurnal Harian}

Berdasarkan hasil jurnal harian peserta didik, sebagian peserta didik merespon positif terhadap pembelajaran Bahasa Indonesia dengan menggunakan Model Pembelajaran Kooperatif-Keliling Kelompok. Pada jurnal harian peserta didik sebagian besar peserta didik tertarik mengikuti pembelajaran Bahasa 
Indonesia yang menggunakan. Model Pembelajaran Kooperatif-Keliling Kelompok Mereka mengemukakan bahwa melalui penggunaan Model Pembelajaran KooperatifKeliling Kelompok, mereka menjadi termotivasi untuk belajar, mudah memahami materi yang sedang dibahas dan mereka lebih bersemangat.

Berdasarkan jurnal harian, sebagian peserta didik merespon positif terhadap pembelajaran Bahasa Indonesia yang menggunakan Model Pembelajaran Kooperatif-Keliling Kelompok.

Dari tabel 4 terlihat peserta didik yang berkomentar positif mengalami peningkatan.

Tabel 4. Persentase Hasil Jurnal Harian

\begin{tabular}{|c|c|c|c|}
\hline Pernyataan & Siklus I & Siklus II & Siklus III \\
\hline Positif & $55 \%$ & $87.5 \%$ & $97 \%$ \\
\hline Negatif & $10 \%$ & 0 & 0 \\
\hline $\begin{array}{c}\text { Biasa-biasa } \\
\text { Saja }\end{array}$ & $35 \%$ & $12.5 \%$ & $3 \%$ \\
\hline
\end{tabular}

\section{KESIMPULAN}

Dari uraian secara keseluruhan, dapat kita lihat bahwa hasil motivasi peserta didik yang dicapai setelah pembelajaran dengan Model Pembelajaran Kooperatif-Keliling Kelompok. Dalam pembelajaran dengan menggunakan Model Pembelajaran Kooperatif-Keliling Kelompok ini, pembelajaran dititik beratkan kepada pentingnya konteks dunia nyata, di mana peserta didik mengaplikasikan pengetahuannya untuk memecahkan permasalahan yang ada di masyarakat. Peserta didik mencari hubungan kesamaan sehingga memperoleh kelompok berdasarkan dari teori yang telah dimiliki dengan memperoleh polapola berdasarkan pengamatan, sehingga peserta didik selain mendapat pengalaman fisik terhadap obyek dalam pembelajaran peserta didik juga memperoleh pengalaman atau terlibat secara mental.

Berdasarkan daya serap rata-rata, maka pada siklus I daya serap rata-rata sebagian besar(67.67), terjadi kenaikan pada siklus 2 sebagian besar (74.28) dan siklus 3 pada umumnya (82.32). Demikian juga dengan daya serap klasikal mengalami peningkatan, pada tindakan I sebagian kecil (25\%) pada siklus 2 sebagian besar $(42.85 \%)$ dan pada siklus 3 pada umumnya (75\%). Data di atas didukung oleh sikap positif peserta didik terhadap pembelajaran Bahasa Indonesia dengan menggunakan Model Pembelajaran Kooperatif-Keliling Kelompok (melalui angket dan jurnal harian peserta didik).

Aktivitas peserta didik dan peneliti guru menunjukan peningkatan pada berbagai langkah dengan baik dan positif sesuai dengan harapan. yaitu langkah: guru menyampaikan materi yang akan disajikan, dan KD yang ingin dicapai; guru membentuk peserta didik berkelompok, lalu memanggil masing-masing ketua kelompok untuk memberikan penjelasan tentang materi; guru membagikan teks pantun; masing-masing ketua kelompok kembali ke kelompoknya masing-masing, kemudian menjelaskan materi yang disampaikan oleh guru kepada temannya. Guru memanggil perwakilan kelompok untuk diberi pengarahan. Guru memberikan permasalahan tentang "Pantun" untuk didiskusikan masingmasing kelompok. Guru memberikan kesempatan kepada kelompok-kelompok kecil saling berkunjung ke kelompok lain untuk melihat pekerjaan kelompok yang lain. Masing-masing anggota kelompok mendapatkan kesempatan untuk memberikan kontribusi dan mendengarkan pengalaman anggota lain. Guru sudah mulai memberikan motivasi secara intensif kepada para peserta didiknya dan peserta didik bersama guru telah bersama-sama membuat kesimpulan dengan baik dan tepat.

Penelitian Tindakan Kelas ini menghasilkan perubahan motivasi dan prestasi peserta didik karena $65 \%$ peserta didik memiliki motivasi yang sangat tinggi. Dengan demikian penggunaan Model Pembelajaran Kooperatif-Keliling Kelompok secara empiris telah terbukti dapat meningkatkan kompetensi peserta didik dalam pembelajaran Bahasa Indonesia di kelas VII.C SMP Negeri 2 Ciparay Kabupaten Bandung Tahun Pelajaran 2017/2018. 


\section{DAFTAR PUSTAKA}

Abidin. (2012). Pembelajaran Bahasa Berbasis Pendidikan Karakter. Bandung: Refika Aditama.

Darmadi. (2017). Pengembangan Model dan Metode Pembelajaran dalam Dinamika Belajar Siswa. Yogyakarta: Slepublish.

Dimyati., \& Mudjiono. (2006). Belajar dan Pembelajaran. Jakarta: PT Rineka Cipta.

Harsiati, T. (2016). Buku Guru Bahasa Indonesia SMP/MTs Kelas VII. Jakarta: Kementerian Pendidikan dan Kebudayaan Republik Indonesia.

Indrayeni, S., Hakim, N., \& Burhanudin, D. (2019). Kemampuan Menulis Pantun Siswa Kelas VII SMP Negeri 2 Lirik. Jurnal Tuah Pendidikan dan Pengajaran Bahasa, 1(1), 69-77.

Lie, A. (2010). Cooperative Learning Mempraktikkan Cooperative Learning di Ruang-Ruang Kelas. Jakarta: Grasindo.

Majid, A. (2014). Strategi Pembelajaran. Bandung: PT Remaja Rosdakarya

Musfah, J. (2011). Peningkatan Kompetensi Guru Melalui Pelatihan dan Sumber Belajar Teori dan Praktik. Jakarta: Kencana.

Pangesti, M. D. (2014). Buku Pintar Pantun; Peribahasa Indonesia. Jakarta: Pustaka Nusantara Indonesia.

Suhana, C. (2014). Konsep Strategi Pembelajaran. Jakarta: Refika Aditama.

Suherman, E. (2003). Evaluasi Pembelajaran Matematika. Bandung: JICA UPI Bandung.

Sukarto. (2010). Pembelajaran menulis cerpen dengan strategi bersafari. [Online]. Tersedia: http://suksesbersamasukarto.blogspot.com/2010/01/pembelajaranmenulis-cerpen-dengan.html [04 Januari 2017].

Sukidin., Basrowi., \& Suranto. (2008). Manajemen Penelitian Tindakan Kelas. Jakarta: Insan Cendekia

Sulkifli \& Marwati. (2016). Kemampuan Menulis Puisi Siswa Kelas Viii SMP Negeri Satu Atap 3 Langgikima Kabupaten Konawe Utara. Jurnal Bastra, 1(1), 1-22.

Taniredja, T. (2013). Model-Model Pengajaran dan Pembelajaran. Yogyakarta: Pustaka Belajar. 